\title{
Metastatic Large Cell Neuroendocrine Carcinoma
}

National Cancer Institute

\section{Source}

National Cancer Institute. Metastatic Large Cell Neuroendocrine Carcinoma. NCI

Thesaurus. Code C158908.

A large cell neuroendocrine carcinoma that has metastasized from its original site of growth to another anatomic site. 